\title{
짧은 아킬레스건의 의미
}

\author{
원성훈, 천동일
}

순천향대학교 서울병원 정형외과

\section{Does Achilles Tendon Shortening Mean Pathologic Lesions?}

\author{
Sung Hun Won, Dong-II Chun
}

Department of Orthopaedic Surgery, Soonchunhyang University Seoul Hospital, Seoul, Korea

This review article attempts to describe several pathological conditions that can arise from the shortening of the Achilles tendon. The tension and tightening of the gastrocnemius-soleus-Achilles tendon complex (GSAC) can cause disharmony in the movement of the entire foot as well as the ankle joint when subjected to weight-bearing or walking. In addition, since these phenomena are observed in various lesions of the ankle joint, the dynamic shortening caused by the tension of GSAC may not be the primary cause of various ankle joint lesions, but is still considered to be a significant contributing factor.

Key Words: Achilles tendon, Plantar fasciitis, Flatfoot, Equinus deformity, Hallux valgus

\section{서 론}

비복근(내측 및 외측)과 가자미근은 아킬레스건과 합쳐져서 종 골(calcaneus)의 후방에 부착하며 비복근의 조임(tightness)은 이 를 통하여 원위부로 전달된다. 따라서 아킬레스건은 체중부하 시에 는 장력이 증가되고, 슬관절의 신전 시에는 족배굴곡(dorsiflexion) 상태로 발목관절을 경직시킨다. 이는 후족부(hindfoot)의 족저굴 곡(plantarflexion) 모멘트(moment)를 증가시키고 동시에 전족부 (forefoot)의 지면 반발력을 증가시켜 보행할 때 전족부에서 후족부 까지의 입각기(stance phase) 후반 모멘트를 증가시키게 된다. ${ }^{1)}$ 이 러한 원리로 비복근 조임 및 긴장(gastrocnemius tightness)의 임 상 증상은 발목이 족배굴곡을 충분히 할 수 없으므로 체중을 지탱하 는 동안의 전족부에 과부하가 걸리기 때문에 발생하는 경우가 많다.

이는 족부족관절의 운동범위뿐만 아니라 각 근육이 부분적으로

Received April 9, 2021 Revised May 21, 2021 Accepted May 24, 2021

Corresponding Author: Dong-II Chun

Department of Orthopaedic Surgery, Soonchunhyang University Seoul Hospital, 59

Daesagwan-ro, Yongsan-gu, Seoul 04401, Korea

Tel: 82-2-709-9250, Fax: 82-2-709-9250, E-mail: orthochun@gmail.com

ORCID: https://orcid.org/0000-0001-7255-8984

Financial support: None.

Conflict of interest: None.
작용하는 힘의 분배와도 관련이 있다. 비복근은 가자미근에 비해 족 관절 운동 중심과의 지렛대 길이(lever arm)가 길다. 따라서 비복근 조임이 있으면 족부 혹은 족관절의 움직임에 비하여 상대적으로 수 축되거나 짧아지는 효과가 커지며 족부족관절의 전체 운동뿐만 아니 라 특정 범위의 운동을 할 때 족배굴곡에 대하여 큰 저항이 작용하게 된다. ${ }^{2)}$ 따라서 비복근 조임으로 인해 능동 혹은 수동적으로 족부족 관절 근육 복합체(족저 및 후방 부위)의 단축-조임이 발생할 수 있고 이는 발 주위의 긴장력을 야기하여 여러 증상이 발생할 수 있음에 유 의해야 한다. 즉 아킬레스-종골-족저 시스템(Achilles-calcaneusplantar system, ACPS)이 보행운동에 관여를 하면서 아킬레스건과 족저근막(plantar fascia)에 작용을 하고, 그 작용에 이상이 생길 때 아킬레스건 긴장, 족저근막염, 편평족, 첨족(equinus) 등의 병변을 야기하는 것이다.

\section{본 론}

\section{1. 아킬레스-종골-족저 시스템}

1954년 Arandes와 Viladot'는 ACPS라는 아킬레스건과 족저근 막을 독립적인 기능적 유닛(unit)으로 연결한 논문을 발표하였다. 그 들은 후방주(posterior column of foot) 시스템으로서 종골이 아킬 
레스건에서부터 발바닥의 내전근으로 힘을 전달하는 큰 종자골(sesamoid bone)로서의 역할을 한다는 주장을 통해 후방 아킬레스건, 족저근막, 그리고 발의 짧은 굴곡건들(plantar intrinsic muscles) 사이의 기능적 연결을 설명하였다. 이 기능적 연결에 대한 개념은 아 킬레스건에서부터 족저근막이 종골 후방결절(posterior tubercle of calcaneus)의 연속된 섬유조직을 통해 해부학적으로 연결이 된 다고 설명한 초기의 해부학 교과서의 내용과도 비슷하다.

이 개념은 발생학적 그리고 계통학적 관점에서 접근하였다. ${ }^{3.4)}$ 먼 저 발생학적인 관점에서는, 배아 조직에서의 아킬레스건과 족저근 막 사이의 육안적 절단 부위에서 조직학적으로 분명한 해부학적 연 속성을 관찰하였다. 이 연결성은 섬유질 내에 2차 골화중심이 나타 나는 7세까지 유지되며 이는 궁극적으로 9세에서 10세 때 종골체 (calcaneal body)와 유합되어 후방결절을 형성한다. ${ }^{3)}$ 또한 계통학 적 관점에서는, 인간의 경우 직립에 적응하기 위해 종골이 거골 아래 에 위치하고 비복근-가자미근-아킬레스건 복합체(gastrocnemiussoleus-Achilles tendon complex, GSAC)를 수동적으로 이완하여 족관절을 90도 이상으로 족배굴곡시킬 수 있게 되었다. ${ }^{4)}$ 이러한 기 전(mechanism)은 체중부하나 보행에서 중요한 의미를 가지게 된 다. 직립 자세에서는 슬관절 이하 전후방 근육 복합체의 긴장 및 수 축을 조절하여 자동적인 균형을 유지할 수 있도록 하고, 보행 시에는 발꿈치 딛기(heel strike)의 자연스러운 족배굴곡과 지면에서 발이 떨어질 때(terminal stance-toe off)의 균형 잡힌(balanced) 지면 반발력을 만들어 준다. 그리고 종골 후방결절을 통한 GSAC와 족저 근육 복합체의 연결성은 체중부하 혹은 보행 시 하퇴부에서부터 발 가락 끝까지 과부하를 줄여주고 효용성을 극대화해주는 역할에 기여 한다.5) 이를 통해 족저근막은 역동학적으로 아킬레스건에서 발바닥 으로 연결된 것임을 유추할 수 있다. 아킬레스건의 힘은 어떤 방식으 로든 종골 후방결절을 거쳐 족저근막으로 전달되고 이를 통해 아킬 레스건의 힘은 발의 짧은 굴곡건까지 연결된다. 이 작용은 보행주기 나 체중부하 시 첨족 자세에서 많이 나타나고 이를 통해 동적인 활동 에서 발꿈치 들기 기전을 설명할 수 있다.

비록 ACPS의 개념이 이러한 기전들을 이해하는 데 도움은 되나 이들 구조물들의 연결 방식이 명확하지 않아 아킬레스건과 족저근막 간의 정확한 해부학적 연결에 대해서는 아직 논란의 여지가 있다. 이 에 대해 아킬레스건과 족저근막 간의 해부학적 연관성을 분석한 사 체 연구와 MRI 연구가 있었지만 그중 일부에서만 이 같은 연결이 발 견되었다. ${ }^{6.7)}$ 또한 그들의 연구는 이런 해부학적 연결이 신생아에서 다양하게 나타나고 성인이 됨에 따라 줄어들며 노년기에는 사라진다 고 보고했다. 이에 따라 연령이 높아짐에 따라 족저근막은 종골의 골 막에 해당하는 얇은 밴드를 통해 근위부로 연결이 되어 아킬레스건 의 건 주위 조직과 연결이 되는 것으로 추론했다(Fig. 1).

\section{2. 아킬레스건과 보행 운동}

정상 보행주기에서 발은 발꿈치 딛기 시기의 유연한 구조에서 발 꿈치 밀기(push off) 시기의 단단한 지렛대 구조로 이행한다. 발의 종아치 형태는 위 기전에 매우 중요한 역할을 하며 뒤꿈치와 제 1,5 중족족지관절(metatarsophalangeal joint)의 족저부로 연결되는 트리포드(tripod)의 세 위치 사이의 전달자로 작용한다. 보행 시 힘 의 동적인 분배가 이뤄지는 과정은 먼저 발목 아래로 내려가는 힘을 먼저 흡수하고, 체중부하가 진행됨에 따라 힘을 후족부에서 전족부 로 신속히 분배하는 식으로 이루어진다. 경거골 관절(족관절)이 발 의 종아치 중심축에 비해 뒤에 위치해 있고 아킬레스건이 그보다 더 뒤쪽에 부착하기에 체중 전달 과정에서 하퇴 삼두근의 과도한 당김 을 야기하는 불균형적인 힘은 여러 경로로 종아치에 과도하게 흩어 지게 된다. 실제로 Thordarson 등은 사체 연구에서 GSAC가 인간의 발 시상면에서 아치 편평화와 횡단면에서 전족부 외전에 가장 크게 기여한다고 하였다. 또한 아킬레스건 조임과 단축이 족관절의 족배 굴곡 시 족부족관절의 수동적 긴장상태를 야기하면서 체중부하 시 족저굴곡 양상의 모멘텀으로 작용하게 된다. 즉 보행의 중간 입각기 (midstance phase)에서 족배굴곡 운동을 저하시키는 방향으로, 그 리고 보행의 입각 말기(terminal stance or propulsive phase)에서 는 족저굴곡 운동을 향상시키는 방향으로 작용한다.

정상 조건에서는 발꿈치 딛기 시기에 다리의 전방구획의 근육들 은 발이 평평해지기 위해 감속하는 동안 편심수축을 하고 후방구획 의 근육들은 이완한다. 발꿈치 딛기 시기에서 중간 입각기에 이르기 까지 GSAC는 기능을 하지 않고, 이것이 긴장되지 않을 때, 거골하관 절의 점진적인 외번이 가능해진다. 후족부가 외반 자세를 취할 때 거

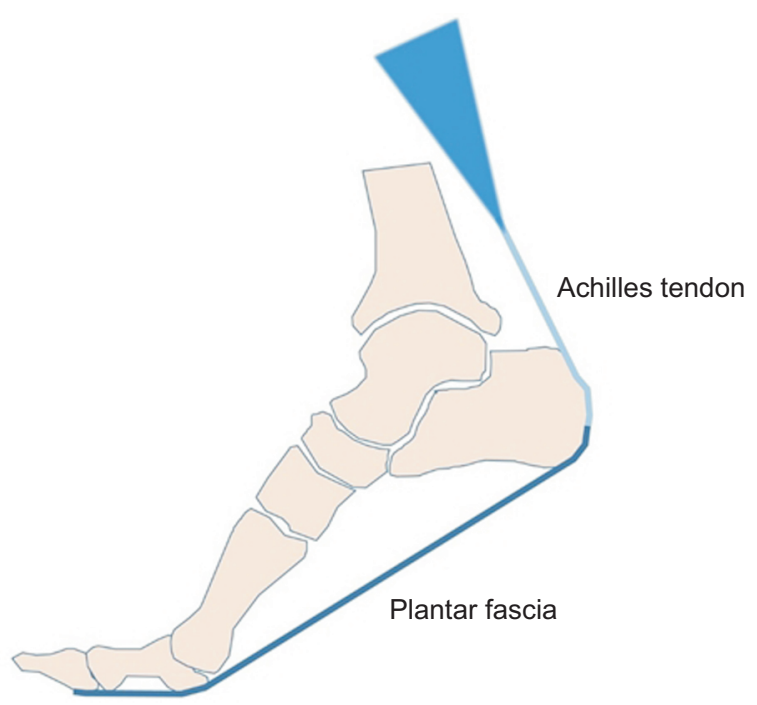

Figure 1. Plantar fascia is connected to the proximal part through the periosteum of the calcaneus, and is connected to the peritendinous tissue of the Achilles tendon. 

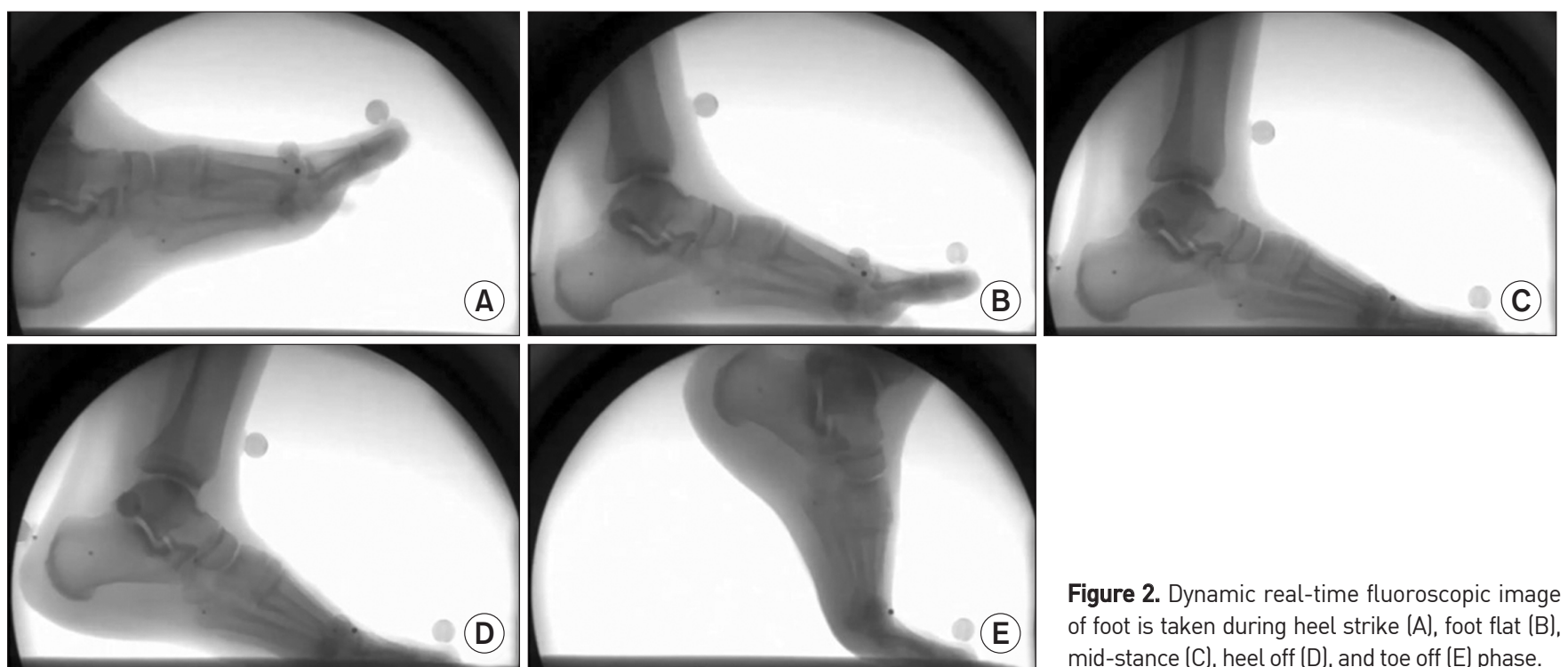

Figure 2. Dynamic real-time fluoroscopic image of foot is taken during heel strike (A), foot flat (B), mid-stance (C), heel off (D), and toe off (E) phase.

주관절과 종입방관절 축은 평행을 이루고 잠금이 풀리며 횡족근관절 을 통해 외전이 허용된다. 정상적으로 기능을 한다면 이 일련의 과정 은 중간 입각기의 충격 흡수를 위해 중족부에서 일어나는 협동운동 의 정도를 증가시킨다. 중간 입각기에서 몸이 발의 앞으로 나아갈 때 무릎은 이완되고 이로 인한 다리 후방 구획 근육의 편심성 수축이 경 골의 전방 모멘텀을 감속시키면서 중족 및 발목을 고정시키는 역할 을 한다. 뒤꿈치 들기(heel rise) 전 뒤꿈치 밀기 시기를 위한 단단한 지렛대를 형성하기 위해 정상 후경골건(tibialis posterior tendon) 은 거골하 내번을 위해 수축하기 시작하고 이는 점진적으로 경골 외 회전, 발목 족배굴곡, 족저근막의 긴장을 유도한다. 이때부터 발생하 는 윈드라스(windlass) 기전은 아치를 상승시키면서 중족 관절을 잠 그고, 아킬레스건의 부착부를 거골하관절 관상면 회전축의 안쪽(내 측)으로 전환시킨다. 이와 같은 자세는 발 바닥 전체를 단단한 지렛 대로 바꾸며 이는 GSAC의 수축과 함께 발꿈치 밀기 시기(입각 말기; terminal stance phase)에 몸을 중족골두로부터 앞으로 전진시킬 수 있게 한다(Fig. 2).

\section{3. 아킬레스건 긴장과 병태생리}

앞에서 기술한 보행 시 여러 작용을 생각하면, 인대 또는 힘줄의 부전으로 인한 내측주의 기능 소실은 이와 같은 일련의 과정을 방해 할 수 있다. 만약 거골하관절이 과도하게 회내전(pronation)된다면 Chopart 관절의 잠금이 풀리게 되고 이는 족배굴곡을 증가시키면 서 족저 연부조직 안정 기전의 역할을 저하시킨다. 따라서 내측 구 조물들이 늘어난다면 이로 인한 아치 안정성의 부족과 부실한 내번 으로 인해 추진 과정에서 전족부로의 효과적인 부하 전달이 어렵게 된다. 이런 작용이 반복될 경우 보행 시 힘의 전달이 중족부를 자연 스럽게 통과하지 못하게 되어 아치는 더욱 평평하게 된다. 발목관절
의 기계적 축(받침점)이 종골 결절(힘이 작용하는 곳)의 체중부하 면 의 앞에 위치하므로(2종 지레) 내측 아치는 보행 중 부하의 충격을 흡수하는 "뒤집힌 용수철(the spring-loaded inverted pendulum, SLIP)"로 불려왔다. ${ }^{9}$ 만약 이 과정에서 단독으로 GSAC 조임이 생기 면 이에 대해 과부하로 인한 반복적인 기계적 스트레스가 결국 비골 장근(peroneus longus), 족저근막, 족저 (스프링) 인대(spring ligament)와 캡슐과 같은 족저의 지지 구조를 서서히 약화시킨다. 나아 가 이로 인해 후경골건에 지속적인 긴장이 가해진다면 힘줄 자체뿐 아니라 내측 구조물에 여러 가지 병적 증상이 발생할 수 있으며 결과 적으로 편평족으로도 진행할 수 있다. 반대로 만약 이런 지지 구조들 의 약화가 먼저 일어난다고 믿는다면 이후 일어나는 일련의 과정들 은 다르게 해석될 수 있다. 즉, 위 지지 구조들의 붕괴가 먼저 일어나 고 이를 통해 외전 변형과 함께 후족부가 초기의 정상 GSAC에 비해 상대적으로 족저굴곡되게 위치하게 된다는 것이다. 족저 지지의 부 족으로 인해 발생한 불가피한 거골의 족저굴곡과 동반된 종골 외번 과 편위는 GSAC의 적응성 단축을 야기하고 이로 인해 보행주기 중 아킬레스건은 신전이 불가능하게 되고 더욱더 조여지게 된다.

이 상관관계에서 어떤 것이 먼저인지에 대한 논쟁과는 무관하게 확실한 것은 일련의 과정이 저절로 끊임없이 계속되는 다음의 두 기 전 조합을 나타낸다는 것이다: (1) 조여진 아킬레스건으로 인해 중족 부 구조로 힘 전달이 증가하고 나아가 그들의 조화된 구조를 변화시 켜 중족부 붕괴를 촉진하고, (2) 후족부의 붕괴는 중족부의 편평화 (flattening) 및 후족부 외번을 가능하게 하여 더욱 하퇴삼두의 조임 을 증가시킨다. 이 반대의 경우도 마찬가지로 타당성 있는 설명이 가 능하고 궁극적으로 유사한 결과를 내게 된다. 하지만 이 연관관계를 규명한 여러 데이터들은 대부분이 사체 연구를 통해 얻어졌고 실제 자연 경과에 대한 연구는 많지 않다(Fig. 3). ${ }^{10}$ 


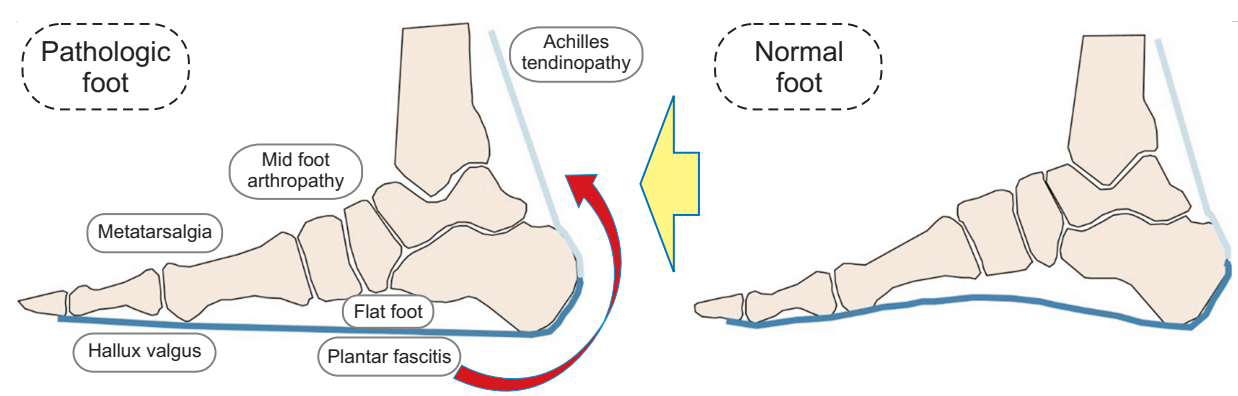

Figure 3. Achilles tendon tightness leads to midfoot destruction by increasing body moment on mid foot structure, while hindfoot destruction leads to tightness on triceps surae by midfoot flattening and hindfoot eversion. And these processes induce pathologic changes such as Achilles tendinitis, plantar fasciitis, metatarsalgia, hallux valgus, flatfoot, and midfoot arthropathy.

\section{4. 아킬레스건과 첨족}

$\mathrm{GSAC}$ 긴장, 조임의 임상 증상은 발목이 족배굴곡을 충분히 할 수 없기 때문에 체중을 지탱하는 동안 앞발의 과부하가 걸려서 발생하 는 경우가 많다. 특히 보행 시 입각기가 끝나면 뒤꿈치가 바닥에서 들어 올려지면서 일시적 가역적 첨족 현상이 발생한다.

이런 원리로 GSAC 조임은 종아리 자체뿐만 아니라 전족부, 족저 근막, 슬관절 및 보행 등에도 영향을 끼치고 여러 가지 상태에서의 족배굴곡 방향으로의 저항을 형성한다.

골성 변형을 배제한다면, 발목 첨족은 일반적으로 GSAC의 구축 에 의해 유발되는 경우가 많다. ${ }^{11)}$ 일반적인 통념과는 다르게 GSAC 의 기능성 단축은 근힘줄 단위 중에서 힘줄 부위보다는 근육 부위에 서 주로 나타난다. 지금까지 발목의 첨족 변형은 두 가지의 형태로 관찰되는 것으로 알려져 있는데, 하나는 비복근 단독으로 영향을 끼 치는 것이고 다른 하나는 비복근과 가자미근 모두에 영향을 끼치는 것이며 이것이 아킬레스 구축으로 알려져 있다. 반면 병적인 가자미 근 단독의 구축은 아직 제대로 규명되지 않았다. ${ }^{12)}$

비록 이와 같은 전신의 이상(특히 신경학적 문제)이 의심할 여지 없이 첨족 구축을 유발하는 주된 원인으로 작용하지만 DiGiovanni 등르은 최근의 연구에서 비복근 단독의 구축이 선행되는 원인이 없는 건강한 개인에서도 첨족이 나타난다고 하였다. 비록 아직 증명되지 는 않았으나 이 경우에 첨족 구축의 원인은 종아리 후방 $2 / 3$ 가량을 차지하는 비복근의 구조적인 특성 및 이 근육이 포함하는 여러 개의 관절로 인한 기계적 영향으로 추정할 수 있다. 첨족 질환으로의 진행 에 이러한 근육들의 단독 또는 여러 개의 긴장이 어느 정도로 기여하 는지에 대해서도 아직 밝혀지지 않았다. 그럼에도 불구하고 확인되 지 않은 강직이 추후 발의 기능에 누적되어 나쁜 영향을 끼칠 수 있 다는 보고가 증가하고 있다. ${ }^{11)}$

\section{5. 아킬레스건과 편평족}

첨족 변형에서 아킬레스건의 역할과의 상호 연관성은 존재하나 그 인과관계를 확실히 규명하기 어려운 것과 마찬가지로 편평족에 있어서도 그러하다. 현재 정의로는 성인 편평족의 경우 성인 시기에
발생한 변형 또는 유아기의 발달성 장애의 후유증에 의해 발생한다. 비록 편평족을 결정하는 여러 징후 및 원인들이 많지만 GSAC 긴장 및 조임 현상은 편평족에서 가장 흔히 관찰되는 이상 소견이다.

편평족과 아킬레스건의 연관성을 설명해 주는 부분들 중 거골의 위치도 중요하다. 일반적으로 거골은 내측 아치의 가장 상방에 위치 한 주상골과 붙어 있고 종골의 내측 주의 하방 지지를 받는다. 따라 서 종골의 정상적인 위치가 무너질 경우(외반, 외회전 등) 거골하관 절 및 거주상관절의 위치가 바뀌게 되고 이는 상대적인 아킬레스건 의 동적 단축 현상을 야기한다. ${ }^{13)}$ 이러한 벡터(vector)의 불균형에 의해서 족저 스프링 인대에 과도한 부하가 걸려 내측 아치의 무너짐 현상이 발생한다. 이와 함께 중족부에서 전족부로 이어지는 역할을 하는 Chopart 관절이 잠금이 이완되고 전족부의 변형도 함께 발생 한다.

편평족 병태생리에 대한 연구가 진행되었음에도 불구하고 긴장된 후방 천층 다리 구획이 위와 같이 진행하는 변형의 가장 적절한 원 인 인자인지 아니면 여러 해부학적인 후유증 중 하나일 뿐인지는 여 전히 불분명하다. 발표된 대부분의 문헌에 따르면 이 두 가지 모두를 지지하는 방향의 해석이 가능한데, 분명한 것은 전통적으로 성인의 후천적 편평족과 소아의 발달성 편평족은 단축되거나 수축된 아킬레 스건과 관련성이 높다는 점이다. ${ }^{14)}$

이러한 일련의 기전들로 인하여 GSAC 조임으로 인한 상대적 단 축 현상은 발의 편평 변형뿐 아니라 족부 전체의 여러 병변과 관련을 갖게 된다.

\section{6. 아킬레스건과 족저근막염}

앞에서 언급한 발의 변형들처럼 족저근막염에서도 아킬레스건의 역할에 대한 상호 연관성은 존재하나 그 인과관계를 확실히 규명하 기 어려운 실정이다. 다만 여러 연구에서 족저근막염의 치료로 아킬 레스건의 스트레칭이 효과적이라고 보고되고 있는 것으로 보아 분명 히 짧아진 아킬레스건과 족저근막염 사이에는 깊은 상관관계가 있음 을 간접적으로 알 수 있다. ${ }^{15)}$ 또한 족저근막염과 짧아진 하퇴근육과 의 관계를 보여주는 연구로는 Patel과 DiGiovanni ${ }^{16}$ 가 보고한 연구 
가 가장 대표적인데, 254 명의 족저근막염 환자 $83 \%$ 에서 족배굴곡 이 제한되었고, $57 \%$ 에서는 비복근의 단독 수축이, $24 \%$ 의 환자에서 는 GSAC의 수축을 보고하였다. 이는 족관절의 족배굴곡의 감소가 족저근막염과 관련이 있다는 것을 보여주는 연구이다. 이러한 원인 을 가장 잘 설명하는 가설은 짧아진 아킬레스건으로 인해 족저굴곡 하는 근력이 약해져서 보행주기 중 발꿈치 밀기에 추진력이 약해지 므로 상대적으로 족저근막에 그만큼의 스트레스가 더 증가하여 족저 근막염을 일으킨다는 설명이다.

\section{7. 아킬레스건과 무지외반증 및 기타 병변}

앞의 설명을 참고하면 아킬레스건과 족무지는 종골을 통하여 족 저근막에 의해 연결된다. 이는 GSAC 긴장, 조임이 족무지까지 영향 을 줄 수 있음을 설명해 준다. ${ }^{17)}$ 알려진 바와 같이 족저근막의 족저 제 1 열측의 섬유결은 제 1 중족족지관절에서 족저부 종자골에 비스 듬한 방향으로 부착되며 이는 족무지의 내측 내재건 및 굴곡건과 연 결되어 있다. 그리고 약간의 무지 외반증이 있는 발에서 족저부의 제 1 중족족지관절을 가로지르는 모든 근육과 힘줄은 족무지의 외반을 증가시킨다. 이는 여러 가지 면에서 무지외반증의 발생에 아킬레스 건이 역할을 할 수 있음을 설명해 준다.

비록 연관성이 크다고는 할 수 없고 논란의 여지도 있으나 이와 같은 잠재적인 상관관계는 후경골건 병변(posterior tibial tendon dysfunction), 아킬레스건염, 발목 염좌, 골절, 족저근막염, 당뇨발 궤양, 샤콧 신경관절염(Charcot arthropathy), 절단, 중족골통, 중 족지골 관절 활액막염, 무지외반증, 갈퀴발가락, 그리고 일반적인 편 평족 변형 등 발의 여러 병적인 진행에서 확인할 수 있다. 그중 문헌 에서는 GSAC 구축과 이에 따른 중족골통, 신경병적 궤양, 족저근막 염, 그리고 어쩌면 샤콧 중족 붕괴로의 진행 간에 가장 강력한 인과 관계가 있음이 규명되었다. ${ }^{18)}$ 이것이 원인과 결과의 관계로 규명되 는지에 대해서는 논란의 여지가 있으나 첨족과 편평족 그리고 전족 부 변형으로의 진행에 대해서는 타당하고 설득력 있는 관련성이 존 재한다. ${ }^{11)}$

\section{결 론}

GSAC 긴장, 조임 현상은 체중부하나 보행 시에 족관절뿐만 아니 라 족부 전체의 운동에 부조화를 야기할 수 있고 이로 인하여 균형 잡힌 힘의 분배가 이루어지지 않음을 확인할 수 있다. 그리고 족부족 관절의 여려 병변에서 이러한 현상들이 관찰되므로 GSAC의 긴장으 로 인한 동적인 단축 현상은 족부족관절 여러 병변들의 주된 인자는 아니지만 상당히 기여하는 원인으로 여겨볼 만할 것으로 생각된다.

\section{ORCID}

Sung Hun Won, https://orcid.org/0000-0002-5471-7432

\section{REFERENCES}

1. Arandes R, Viladot A. [Biomecánica del calcáneo]. Minerva Chir. 1954;9:439-46. Spanish.

2. DiGiovanni CW, Kuo R, Tejwani N, Price R, Hansen ST Jr, Cziernecki $\mathrm{J}$, et al. Isolated gastrocnemius tightness. J Bone Joint Surg Am. 2002;84:962-70. doi: 10.2106/00004623-200206000-00010.

3. Meyer DB, O'Rahilly R. The onset of ossification in the human calcaneus. Anat Embryol (Berl). 1976;150:19-33. doi: 10.1007/ BF00346283.

4. Vieira L. Phylogenetics of the fascial system. Cureus. 2020;12:e10787. doi: 10.7759/cureus. 10787.

5. Zwirner J, Zhang M, Ondruschka B, Akita K, Hammer N. An ossifying bridge - on the structural continuity between the Achilles tendon and the plantar fascia. Sci Rep. 2020;10:14523. doi: 10.1038/s41598-02071316-Z.

6. Singh A, Zwirner J, Templer F, Kieser D, Klima S, Hammer N. On the morphological relations of the Achilles tendon and plantar fascia via the calcaneus: a cadaveric study. Sci Rep. 2021;11:5986. doi: 10.1038/ s41598-021-85251-0.

7. Stecco C, Corradin M, Macchi V, Morra A, Porzionato A, Biz C, et al. Plantar fascia anatomy and its relationship with Achilles tendon and paratenon. J Anat. 2013;223:665-76. doi: 10.1111/joa.12111.

8. Thordarson DB, Schmotzer H, Chon J, Peters J. Dynamic support of the human longitudinal arch. A biomechanical evaluation. Clin Orthop Relat Res. 1995;(316):165-72.

9. Antoniak G, Biswas T, Cortes N, Sikdar S, Chun C, Bhandawat V. Spring-loaded inverted pendulum goes through two contraction-extension cycles during the single-support phase of walking. Biol Open. 2019;8:bio043695. doi: 10.1242/bio.043695.

10. Ballal MS, Walker CR, Molloy AP. The anatomical footprint of the Achilles tendon: a cadaveric study. Bone Joint J. 2014;96-B:1344-8. doi: 10.1302/0301-620X.96B10.33771.

11. DiGiovanni CW, Langer P. The role of isolated gastrocnemius and combined Achilles contractures in the flatfoot. Foot Ankle Clin. 2007;12:363-79, viii. doi: 10.1016/j.fcl.2007.03.005.

12. Johnson $\mathrm{CH}$, Christensen JC. Biomechanics of the first ray part $\mathrm{V}$ : the effect of equinus deformity. A 3-dimensional kinematic study on a cadaver model. J Foot Ankle Surg. 2005;44:114-20. doi: 10.1053/ j.jfas.2005.01.003.

13. Johnson KA, Strom DE. Tibialis posterior tendon dysfunction. Clin Orthop Relat Res. 1989;(239):196-206.

14. Blackman AJ, Blevins JJ, Sangeorzan BJ, Ledoux WR. Cadaveric flatfoot model: ligament attenuation and Achilles tendon overpull. $J$ Orthop Res. 2009;27:1547-54. doi: 10.1002/jor.20930.

15. Engkananuwat P, Kanlayanaphotporn R, Purepong N. Effectiveness of the simultaneous stretching of the Achilles tendon and plantar fascia in individuals with plantar fasciitis. Foot Ankle Int. 2018;39:75-82. doi: $10.1177 / 1071100717732762$. 
16. Patel A, DiGiovanni B. Association between plantar fasciitis and isolated contracture of the gastrocnemius. Foot Ankle Int. 2011;32:5-8. doi: 10.3113/FAI.2011.0005.

17. Snow SW, Bohne WH, DiCarlo E, Chang VK. Anatomy of the Achilles tendon and plantar fascia in relation to the calca- neus in various age groups. Foot Ankle Int. 1995;16:418-21. doi: 10.1177/107110079501600707.

18. Ramanujam CL, Zgonis T. Surgical correction of the Achilles tendon for diabetic foot ulcerations and Charcot neuroarthropathy. Clin Podiatr Med Surg. 2017;34:275-80. doi: 10.1016/j.cpm.2016.10.013. 